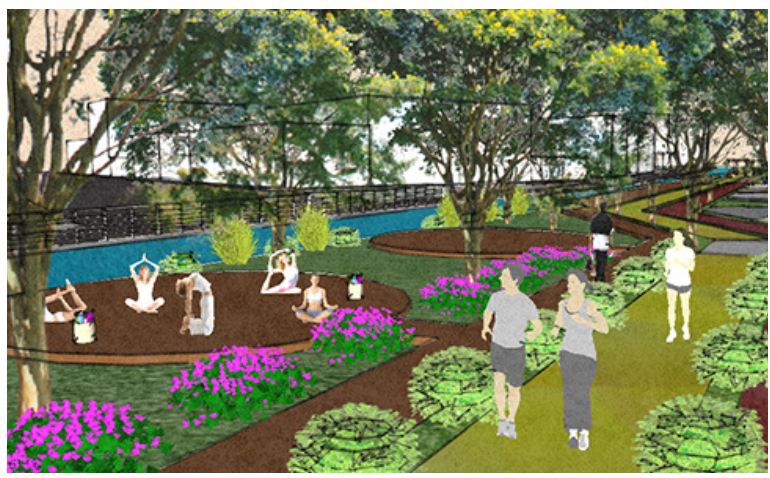

*Arquiteta e Urbanista. Mestranda em Arquitetura e Cidade pela Universidade Vila Velha (bolsa FAPES), integrante dos Grupos de Pesquisa "Paisagem Urbana e Inclusão" e "Dignidade Urbana".. Estuda Planejamento e Projeto de Espaços Livres, Gestão e Desempenho da cidade e Vitalidade Urbana. Atua profissionalmente na área de Projeto Arquitetônico, Paisagístico e Urbanístico.

${ }^{\star *}$ Arquiteta e Urbanista. Doutora em Tecnologia e Projeto para a Qualidade Ambiental na escala da arquitetura e da cidade. Professora do curso de Arquitetura e Urbanismo e do Mestrado em Arquitetura e Cidade da Universidade Vila Velha. Líder do Grupo de

Pesquisa "Paisagem Urbana e Inclusão". Estuda Planejamento e Projeto de Espaços Livres, Qualidade Ambiental do Ambiente Construído, Vitalidade Urbana e Ensino de Arquitetura e Urbanismo.

${ }^{\star * \star A r q u i t e t a ~ e ~ U r b a n i s t a ~}$ Doutora e Mestre em Cidade, Segurança e Saúde. Professora e Coordenadora do Mestrado em Arquitetura e Cidade e professora do Curso de Graduação em Arquitetura e Urbanismo da Universidade Vila Velha. Líder do Grupo de Pesquisa "Dignidade Urbana". Estuda Planejamento e Projeto de Espaços Livres, Planejamento Urbano e Regional, Vitalidade Urbana e Ensino de Arquitetura e Urbanismo.

usjt • arq.urb • número 24 | janeiro - abril de 2019

\title{
Espaço público e vitalidade: Parque linear como instrumento de reconciliação em área residual da infraestrutura viária
}

Public space and vitality: linear park an instrument of reconciliation in residual streetscape area

Suzany Rangel Ramos*, Larissa Leticia Andara Ramos ${ }^{\star \star}$ e Ana Paula Rabello Lyra***

\section{Resumo}

A qualidade de vida da população em meio urbano é influenciada pela presença de espaços públicos de permanência e lazer. Essses, por sua vez, são também corresponsáveis pela dinamização e vitalidade urbana. Todavia, o planejamento urbano das cidades contemporâneas reflete um distanciamento das relações entre as pessoas e os espaços livres de uso público, uma vez que estes são suprimidos pelas áreas edificadas e vias de circulação de veículos motorizados. O presente artigo reconhece a importância da produção desses espaços nas cidades e propõe estudar uma proposta de reconciliação urbana para reverter um desses cenários, situado em área remanescente da malha viária de uma parcela urbana da Região Central do município de Vila Velha - ES. A área identificada possui grande potencial para a criação de um espaço livre de uso público que atenda a demanda local, capaz de reverter a ruptura criada pelas obras de infraestrutura que cobriram o Canal Bigossi, que corta a cidade. A estratégia adotada resultou no ensaio projetual de um parque linear, desenvolvido em âmbito acadêmico, que consistiu na proposição de um espaço plural, abrigando múltiplas atividades e serviços, numa configuração que permite aproximar a relação entre a população, o meio ambiente e a cidade.

Palavras-chave: Espaços Públicos. Vitalidade Urbana. Parque Linear.

\section{Abstract}

Quality of life in urban areas is often influenced by the existence of public open spaces. These places are co-responsible for the urban vitality and dynamics of the cities. Nevertheless, contemporary city planning is reflecting a contradictory distance from issues regarding social factors in urban open spaces. This is noticed by the amount of city space dedicated to buildings and roads. This paper recognizes the importance of public open spaces to the cities and addresses efforts to study a proposal for an urban reconciliation of a residual streetscape area, located in the Central region of Vila Velha municipality, in the State of Espírito Santo, Brazil. This area has great potential for a new public open space to attend local needs, able to reverse the rupture created by the infrastructure works that covered the Bigossi canal. The chosen strategy resulted in a linear park design, an academic project developed in the last year of the undergraduate program in architecture and urban planning. The design proposed a plural open space that embraced multiple activities and services configured to join people, environment and the city all together.

Keywords: Public Spaces. Urban Vitality. Linear Park. 


\section{Introdução}

1. Lazer passivo compreendido por aquelas atividades relacionadas ao baixo esforço físico como a meditação, contemplação e leitura, enquanto o lazer ativo é compreendido por aquele relacionado a atividades físicas, como esporte, corrida e caminhada.

usjt • arq.urb • número 24 | janeiro - abril de 2019 processo de urbanização das cidades contemporâneas gera pressões no uso e ocupação do solo urbano e, nesse contexto, os espaços livres, essenciais para $o$ as práticas sociais inerentes aos espaços públicos do meio urbano, são substituídos por áreas construídas, afetando diretamente a população residente. A qualidade de vida da população depende dessas oportunidades de trocas e encontros propiciadas pelas áreas de lazer públicas, identificadas como espaços democráticos de direito do cidadão, para garantia do pleno desenvolvimento das funções sociais da cidade (BRASIL, 2002).

O planejamento das cidades deve levar em consideração o dinamismo que a criação de espaços públicos tem a oferecer. Esses espaços influenciam na saúde física e mental da população, na medida em que acolhem diversidades de possíveis apropriações de lazer passivo e ativo ${ }^{1}$. Segundo Gehl (2015), o ponto natural de partida para se projetar cidades para pessoas é a relação entre mobilidade e os sentidos humanos, pois é nesse vinculo que se define o comportamento humano e sua comunicação com o espaço urbano. Ainda de acordo com Gehl (2015), o desafio dos urbanistas é mais que simplesmente planejar espaços que garantam a circulação de pessoas:

Destaca-se dessa discussão a sociabilidade, essencial para estruturação dos processos de transformações urbanas. Nesse cenário, os aspectos de urbanidade são relevantes para promoção das relações entre os espaços edificados e os espaços livres de uso público, a fim de possibilitar maior interação da população com o meio natural que a circunda (AGUIAR; NETTO, 2012). é projetar espaços que possibilitam o contato direto com a sociedade em seu entorno, através da criação de espaços vivos, multifuncionais e diversos.

Esse artigo é um desdobramento da pesquisa "Espaços livres de uso público do município de Vila Velha - ES" que identificou espaços livres da 
Região Central do município e apontou terrenos potenciais para futuras intervenções que equilibrassem a má distribuição dos espaços livres de uso público entre os bairros da região. Busca refletir a importância da produção desses espaços nas cidades apresentando discussões levantadas no trabalho de conclusão de curso "O espaço público em busca de uma cidade viva" que identificou, em uma área remanescente da malha viária na Região Central do município de Vila VeIha - ES, um espaço com potencialidade para reverter o cenário local de ruptura e fragmentação, através da inserção de um Parque Linear.

Como procedimento projetual adotou-se a tipologia de Parque Linear, cuja configuração de implantação permite reconciliar os bairros do entorno compreendidos por Cristóvão Colombo, Divino Espírito Santo e llha dos Ayres, atualmente desprovidos de infraestrutura destinada à apropriação e uso público.

A fundamentação teórica da pesquisa foi realizada a fim de compreender a importância dos espaços públicos no contexto da cidade contemporânea. Inclui nessa discussão a participação popular no planejamento e desenho urbano trazendo como referencias as contribuições recentes dos autores como Bava (2000), Nygaard (2010), Alex (2011), Gatti (2013) e Netto (2014). A revisão bibliográfica também buscou fundamentar a produção de parques urbanos, com foco na compreensão da tipologia de parques lineares, tendo como principais autores Scalise (2002), Serpa (2013) e Sakata (2018).

A caracterização e o diagnóstico da área foram realizados a partir de levantamento de dados via ferramentas digitais como Google Earth e Street View, além de visitas de campo. Os mapeamentos e diagramas de análise foram ilustrados em forma de croqui, sobre imagem aérea de satélite. Também foram utilizadas imagens 3D, no programa SketchUp, para as ilustrações referente ao ensaio projetual.

A partir das discussões levantadas acerca da produção de espaços públicos na cidade contemporânea entende-se que a abordagem possui relevância, a medida em que a garantia ao espaço público e lazer é um direito de todo cidadão. Discussões e experiências projetuais sobre esse tema visam contribuir para que o poder público e a população busquem melhorias no planejamento das cidades.

\section{O planejamento urbano da cidade contempo- rânea e seus espaços livres de uso público}

A cidade contemporânea tem se consolidado a partir de inversões de valores tradicionais de urbanidade. Essa realidade vem se intensificando na medida em que a população multicultural e diversificada da cidade aumenta, impondo novos desafios e demandas para a vida urbana. Para Mongin (2009), a cidade pode ser definida como 
um lugar praticado que caracteriza a condição urbana ativa e essa deve produzir espaços públicos qualificados que permitam experiências e participação dos usuários, para que esses exerçam seu direito à cidade. Apesar disso, o cenário atual aponta para o desaparecimento desses espaços, fato que, segundo Rogers (2001), pode acarretar grandes problemas sociais que caracterizam o declínio da cidade.

Ainda nesse contexto, Netto et al (2017) afirmam que essas mudanças estruturais na cidade são fortes o bastante para alterar o modo como o ser humano usa e vive esses espaços. Tende-se a introversão da vida urbana, onde as construções são fragmentadas, dificultando a apropriação do espaço público e induzindo a dependência veicular. Sendo assim, Netto (2014) aponta que, atualmente, uma das principais preocupações é compreender a cidade contemporânea como o locus da pluralidade, da convivência entre atores socialmente diferentes e do reconhecimento do espaço de coexistência, evidenciando a importância da produção de espaços públicos e do seu potencial na reconciliação de fragmentos da cidade.

De acordo com Brandão (2008), os espaços públicos são definidores da forma urbana, uma vez que configuram a socialização e a vivência comum como um bem coletivo da comunidade. Esses devem ser vistos como local de utilização livre, que traduz o equilíbrio entre o meio e o ho- mem. Segundo Alex (2011), esses espaços são locais abertos e acessíveis a todas as pessoas, podem assumir formas e tamanhos variados e devem ser vistos como um conjunto de práticas sociais, abrangendo praças, parques, ruas e jardins. A articulação desses espaços com o tecido urbano define sua conexão com a cidade, tanto que o convívio e interrelações sociais que acontecem também dependem dessa relação. Esses podem, de acordo com Nygaard (2010), representar a vitalidade ou a estagnação da vida urbana, pois são capazes de incorporar usos econômicos e sociais variados através de práticas socioespaciais.

Um espaço público seguro e não excludente, seja ele de pequeno ou grande porte, conforme afirma Rogers (2001), é fundamental para a coesão social, pois serve de palco para a expressão da democracia. Nesses espaços a população tem liberdade para debater sobre os direitos cidadãos e estimular essas discussões. A falta deles, conforme afirma Santiago e Marchesano (2016), caracteriza uma cidade com relações sociais frágeis e tensas. A vida coletiva dos espaços públicos é também para Gatti (2013) um indicador de qualidade de vida de uma cidade, por ser local de lazer, descanso, conversa, circulação e encontro de pessoas. Sendo assim, devem ser espaços projetados através da compreensão da dinâmica urbana a fim de refletirem as necessidades e anseios dos usuários. 
Gatti (2013) indica alguns elementos essenciais para a construção de espaços públicos de qualidade: mobilidade; acessibilidade; arborização; segurança e conforto, além da importância de se pensar as atividades que o espaço pode acoIher e seu apelo visual. Brandão (2008) também aponta elementos como: identidade, continuidade e permeabilidade - a fim de proporcionar boa integração com a malha viária; adaptabilidade, diversidade e flexibilidade - principalmente quando diz respeito aos usos; e sustentabilidade - na esfera econômica, ambiental, social e cultural. Estes elementos, quando aliados, constituem condições favoráveis para apropriação dos espaços públicos.

Apesar da existência de referências sobre como qualificar os espaços públicos na cidade contemporânea, Alex (2011) afirma que nem sempre os projetos resultam em espaços mais convidativos ou adaptáveis a presença da população. De acordo com o autor, apesar dos discursos bem-intencionados alguns dos novos espaços mostram-se fechados e hostis, negando o encontro e o convívio pretendidos. A configuração desse espaço, ao afetar o convívio social, interfere também no exercício da cidadania e na construção da democracia. É nesse contexto que se ressalta a importância da participação popular nos processos de planejamento urbano, e nas decisões que envolvem o desenho e os usos de cada espaço das cidades.
Bava (2000) afirma que a participação de representantes da sociedade civil nos processos decisórios do governo é o elemento determinante da democratização da cidade, a medida em que são criados espaços de negociação dos distintos interesses presentes entre os diferentes setores sociais existentes na sociedade. De acordo com Nygaard (2010, p. 53) "a população, ao ser excluída do processo de intervenção da cidade, não reconhece a cidade contemporânea como o espaço do dia-a-dia, da vida cotidiana, como espaço que contém seus referentes, suas práticas e seus valores". E dessa forma, Saboya (2014) acrescenta que no processo de planejamento existem inúmeros aspectos a serem levados em consideração, e que, ouvir a população é essencial para entender seus desejos, aspirações, prioridades e valores de forma mais aprofundada.

Segundo Del Rio (1990), todas essas decisões, apresentadas num processo de planejamento colaborativo, influenciam diretamente no desenho urbano das cidades e suas diferentes escalas, promovendo como consequência a qualidade físico-ambiental destas. Ainda de acordo com o autor, são as vivências, percepções e ações cotidianas da população que definem, através de suas atividades, a dimensão espacial do desenho urbano. Dentro desse tema, além das questões comportamentais dos usuários, discute-se também a importância de elementos físicos como: uso do solo; configuração espacial; circulação de veículos e pedestres; espaços livres; programa 
de atividades e mobiliário urbano, que impactam decisivamente na qualidade final do processo de planejamento urbano (DEL RIO, 1990).

\section{Parque Urbano Linear como tipologia proje-} tual

Os espaços livres da cidade podem oferecer variados tipos de configuração, implantação e programa, de acordo com a demanda e contexto em que se inserem. Dentre as tipologias que a cidade pode oferecer, este trabalho busca fomentar a reflexão acerca do papel dos Parques Urbanos na estruturação qualificada da cidade. Para isso, a discussão traz como enfoque a implantação de Parques Lineares, que, levando em consideração sua configuração espacial, adequam-se melhor na realidade da área de estudo deste trabalho.

Segundo Macedo e Sakata (2003), o Parque Urbano é um espaço livre de uso público que atende solicitações de recreação e lazer da população, podendo ser voltado a atividades esportivas, culturais, com intenções de conservação da área. Sá Carneiro e Mesquita (2000) complementam que são espaços que apresentam componentes da paisagem natural como vegetação, topografia, elementos aquáticos e também edificações destinadas a atividades recreativas, culturais e/ ou administrativas. Mascaró (2008) afirma que são espaços abertos envolvidos por vias de circulação e que permitem boa conexão com o sistema de transporte público e privado da cidade, onde há predominância de áreas verdes.
Serpa (2013) destaca a importância socioambiental e cultural dos Parques Urbanos na medida em que: a) funcionam como meio de controle social, conferindo qualidade estética ao local de implantação e seu entorno; b) auxiliam na preservação da natureza, estimulando a implantação de áreas verdes; c) compõem o patrimônio da cidade, tornando-se referência e símbolo de identidade; d) funcionam como espaço estruturador de vínculos e relações sociais, melhorando a qualidade de vida e resolvendo os conflitos sociais; e também e) contribuírem para o prestígio da área onde estão inseridos, revalorizando a paisagem local.

Em relação aos parques lineares, de acordo com Scalise (2002), estes foram criados para uso recreativo. Hoje, pela configuração linear na maIha urbana, são utilizados como corredores de conexão entre diversos destinos da cidade. Sua implementação valoriza o entorno e melhora a qualidade de vida da população, concentrando atividades ligadas ao esporte, cultura e lazer. É um espaço de fácil acesso e democrático pois não beneficia apenas uma área dentro da cidade. Scalise (2002) afirma ainda que existem alguns pontos que devem ser levados em consideração na concepção desses espaços: a) conexão com os bairros locais e com outros lugares de interesse da população; b) segurança, devendo evitar perigos a partir da permeabilidade e continuidade de sua forma, e c) fiscalização, realizada por autoridades e seus usuários. 
Segundo Soluções para Cidade (sem data), os parques lineares são áreas destinadas à conservação e à preservação de recursos naturais; capazes de interligar fragmentos de paisagem, agregar funções de uso humano, como por exemplo atividades de lazer e cultura, além de formar rotas de locomoção através das ciclovias e dos caminhos para pedestres. Apesar de serem muito utilizados como instrumentos de recuperação de áreas ambientais degradadas, podem também servir como espaços recreacionais, criando infraestruturas alternativas para a cidade. Sakata (2018) afirma que os parques lineares compõem um sistema de novas categorias de parques, que começaram a ser implantados, principalmente, após os anos 2000. Segundo a autora, estes podem ser categorizados em: a) parques lineares inseridos na malha urbana: que possuem o comprimento muito maior que a largura e são inseridos em malhas urbanas mais densas; b) parques lineares ao longo de rios: que criam conexões urbanas, inclusive entre as paisagens naturais; e c) parques lineares aéreos: que utilizam antigas infraestruturas sobre viadutos.

Ainda de acordo com Sakata (2018) os parques lineares podem configurar espaços muito estreitos que, em alguns trechos, formam uma rede de pequenos espaços públicos articulados com as vias. Porém ao mesmo tempo, em outros trechos, são largos e permitem que o usuário não perceba a malha urbana e consiga vivenciar as atividades propostas. Em um parque linear, a relação desses espaços com as vias circundantes é bem mais próxima, por isso precisam ser atravessados por um grande número de pessoas, ponto fundamental que condiciona a sua abertura, livre acesso e circulação.

As discussões apontadas por Sakata (2018) sobre a implantação dos parques lineares refletem a realidade da área de estudo, que será apresentada a seguir. A área proposta para a intervenção possui grande extensão em seu comprimento e grandes variações em sua largura, assim como caracteriza a autora, permitindo diferentes propostas ao longo de seu percurso. A presença de um canal e o intuito de trazer à tona a paisagem natural do local também condiciona e fortalece a justificativa da implantação de um parque linear como procedimento projetual adequado ao contexto.

\section{Caracterização da área de estudo para inter- venção}

O município de Vila Velha integra a região metropolitana do estado do Espírito Santo e, de acordo com a Lei Municipal $n^{\circ}$ 4.707/2008 (VILA VELHA, 2008), é dividido em 05 (cinco) Regiões Administrativas. Dentre estas, a Região Central (em azul na Figura 1) foi identificada como objeto de estudo da pesquisa "Espaços livres de uso público do município de Vila Velha - ES" por possuir grande importância na dinâmica socioeconômica, 
cultural e turística da cidade. A Região, que tem a orla a leste como delimitador, é composta por 18 (dezoito) bairros (como ilustrado no último mapa da Figura 1), e, de acordo com os dados da SEMPLA (2013), abrange 35\% da população do município num território que representa apenas 7\% de sua área.

Sobre o tema dos espaços livres de uso público abordado na pesquisa, o planejamento urbano do município de Vila Velha traz alguns objetivos, diretrizes e ações quanto a política de áreas verdes, praças e parques urbanos da cidade. De acordo com o Projeto de Lei Complementar $\mathrm{n}^{\circ}$ 065/2018 (VILA VELHA, 2018) é de interesse do poder público ampliar as áreas verdes e assegurar usos compatíveis com a proteção dessas áreas. Uma das ações estratégicas dessa política é garantir a gestão compartilhada de praças e parques urbanos, além de criar interligações entre esses espaços através do uso da vegetação urbana. A criação de Parques Urbanos também é um dos objetivos das Zonas Especiais de Interesse Ambiental (ZEIA), além da compatibilização com as atividades de lazer, turismo e educação ambiental (VILA VELHA, 2018).

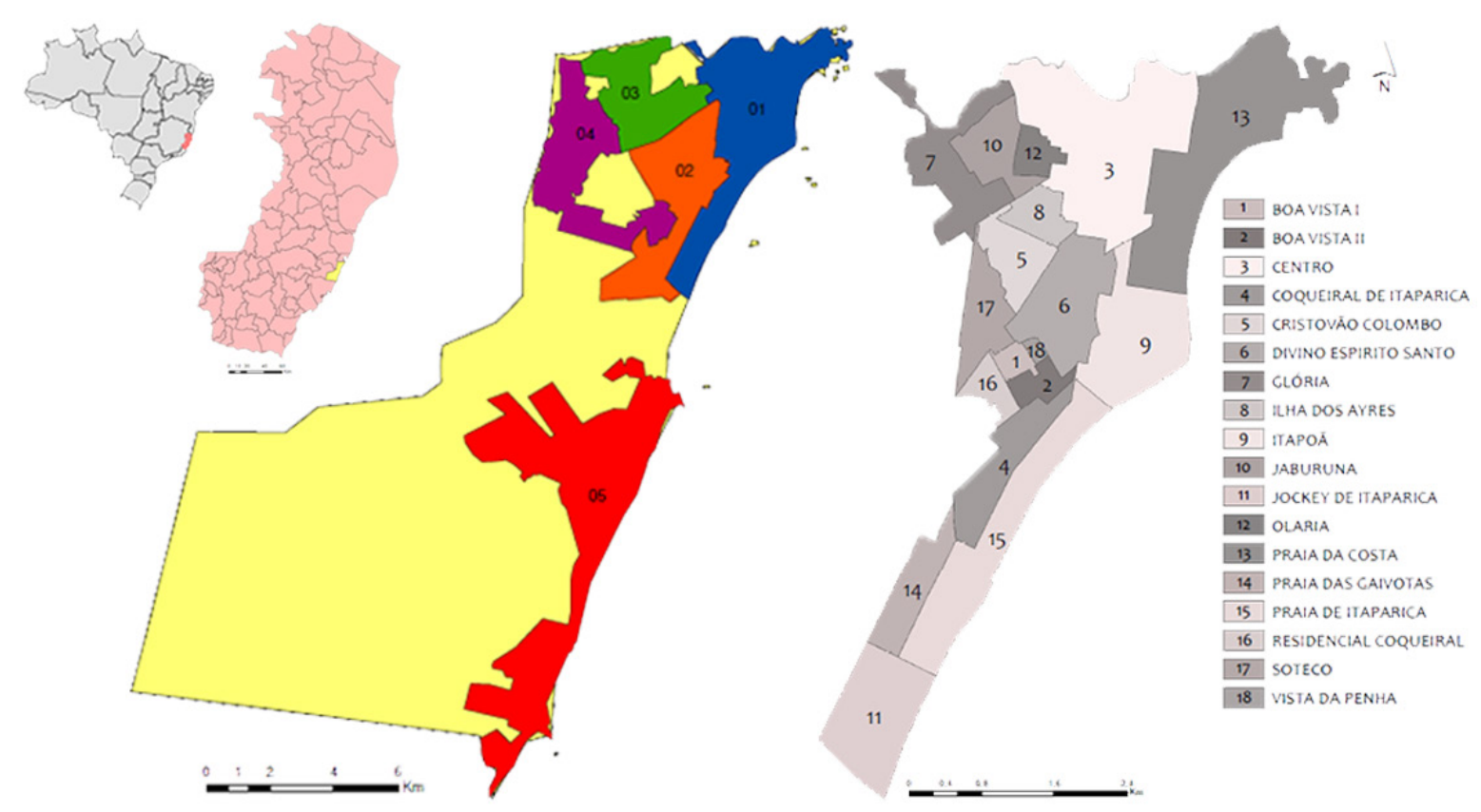

Figura 1. Localização do município de Vila Velha no contexto nacional e estadual. Em seguida, mapa do município, evidenciando, em azul, a regional central e a divisão em bairros. Fonte: Elaboração própria a partir de base cartográfica do ArcGIS, 2017. 
Nesse contexto, para a escolha da área de intervenção desse estudo foram utilizados dados coletados por Ramos e Jesus (2017) que mapearam, no âmbito da Região Central do município de Vila Velha, espaços públicos para práticas sociais (praças e parques) e terrenos potenciais para a proposição de novos espaços públicos que suprissem a demanda da população. Como ilustra a sequência da Figura 2 a seguir, nos espaços públicos para práticas sociais identificados foi traçado, a partir dos espaços existentes e potenciais, um raio de 300 metros de abrangência. Esse indicador representa um tempo de cerca 3 a 4 minutos de caminhada do pedestre. O referido raio visa ilustrar a área de influência para auxiliar na criação de novos espaços públicos na área de

estudo que atenda a demanda população.

Dentre os espaços potenciais mapeados na Região Central, conforme ilustra a Figura 2 acima, foram identificados terrenos "prioritários" para a proposição de novos espaços públicos. Estes estão localizados em áreas não contempladas pelo mapeamento dos espaços livres de uso público para práticas sociais e suas áreas de abrangências - considerando o raio de influência de 300 metros. É possível verificar, a partir do terceiro mapa da Figura 2, que se os terrenos prioritários fossem utilizados para a criação de espaços públicos a maior parte da população da Região Central poderia acessar, confortavelmente, esses equipamentos.
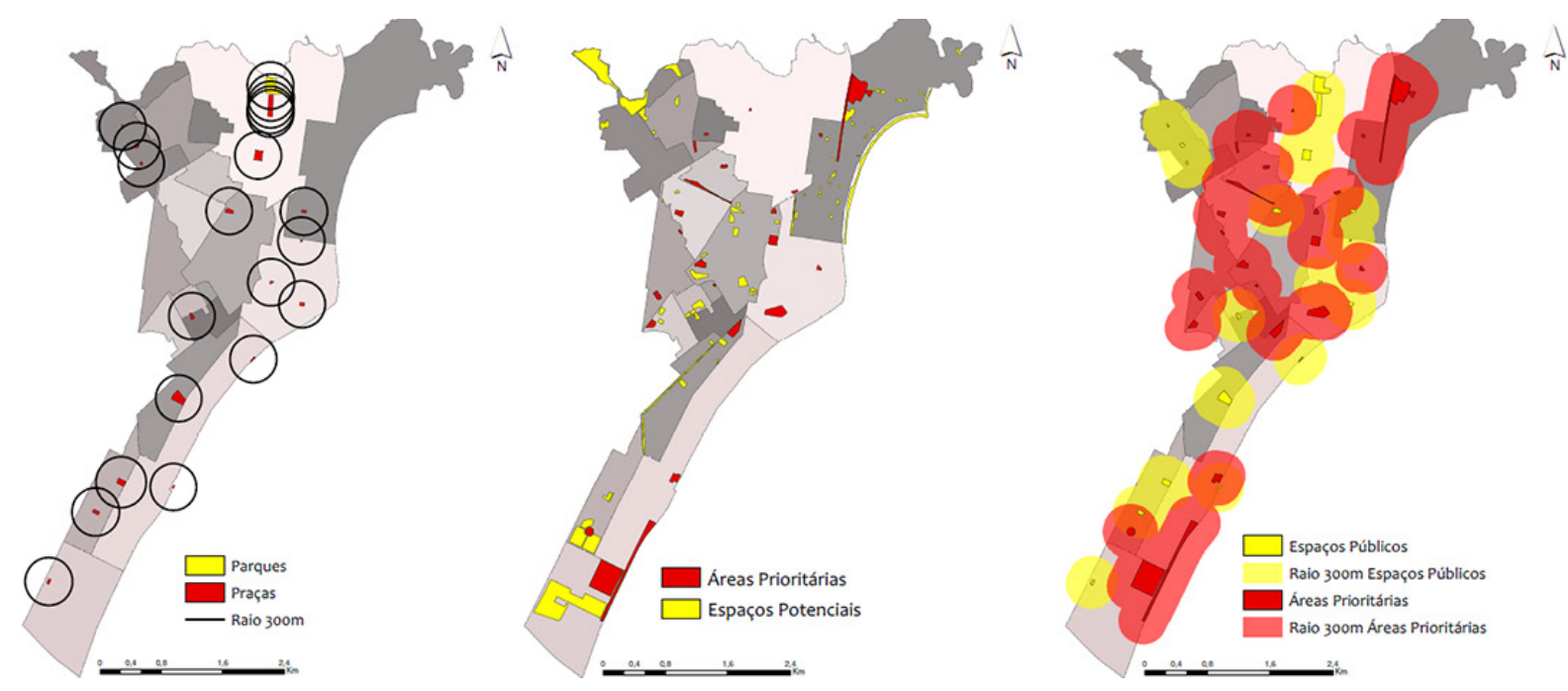

Figura 2. Mapeamento dos espaços livres de uso público (praças e parques) da Regional Central e seus raios de influência. No segundo mapa, o mapeamento das áreas prioritárias e espaços potenciais. Na sequência, a abrangência dos espaços livres considerando os espaços existentes e os espaços potenciais prioritários. Fonte: Elaboração própria a partir de base cartográfica do ArcGIS, 2018. 
A área objeto de intervenção deste estudo, identificada dentre aquelas com potencial de intervenção, trata-se de um espaço residual da maIha viária, localizado entre os bairros Cristóvão Colombo, Divino Espírito Santo e llha dos Ayres, como ilustra a Figura 3 a seguir. A longa extensão; a presença de um canal (parcialmente coberto); a ociosidade em meio a malha urbana; a proximidade com o terminal rodoviário (identificado com asterisco na Figura 3); a falta de espaços livres de uso público em seu entorno; e a desconexão entre os bairros adjacentes foram elementos que condicionaram um local favorável para a proposição de um Parque Linear.
Esse espaço residual é decorrente de uma obra de infraestrutura e mobilidade urbana realizada pela Prefeitura Municipal de Vila Velha e o Governo do Estado. A obra consistiu na drenagem, construção da galeria e na cobertura de parte do Canal Bigossi, além da pavimentação e abertura de novas vias, que deram prioridade ao grande fluxo de veículos. A justificativa do poder público para tal intervenção foi a de facilitar a conexão de veículos entre dois importantes eixos de mobilidade da cidade: a Terceira Ponte - que liga a cidade de Vila Velha à capital Vitória - (em vermelho na Figura 3) e a Avenida Carlos Lindemberg (em amarelo na Figura 3) (MARTINS; OLIVEIRA;THOMAZ, 2009).

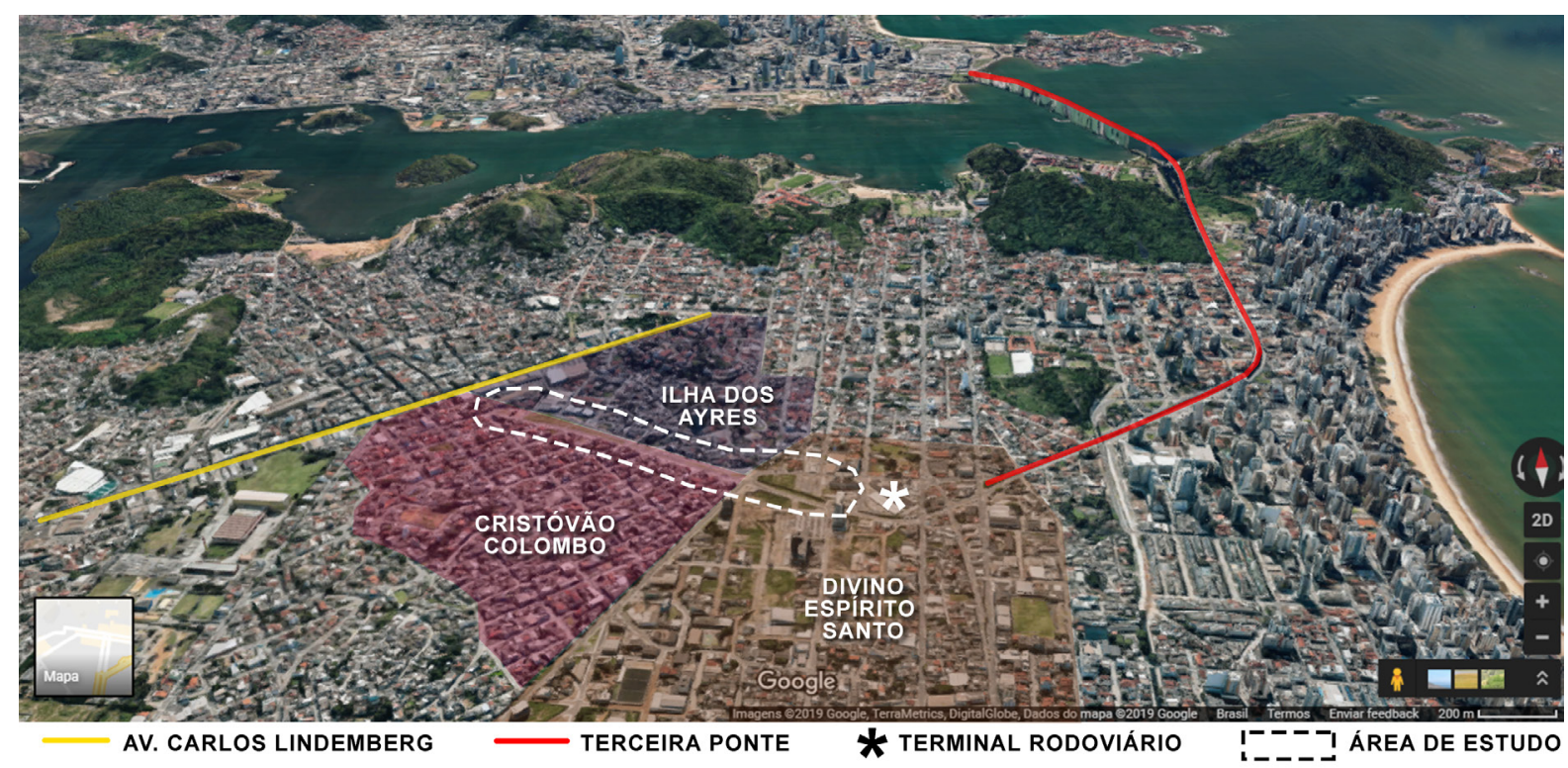

Figura 3. Localização da área de estudo para ensaio projetual. Fonte: Elaboração própria a partir de imagem aérea disponibilizada no Google Earth, 2019. 

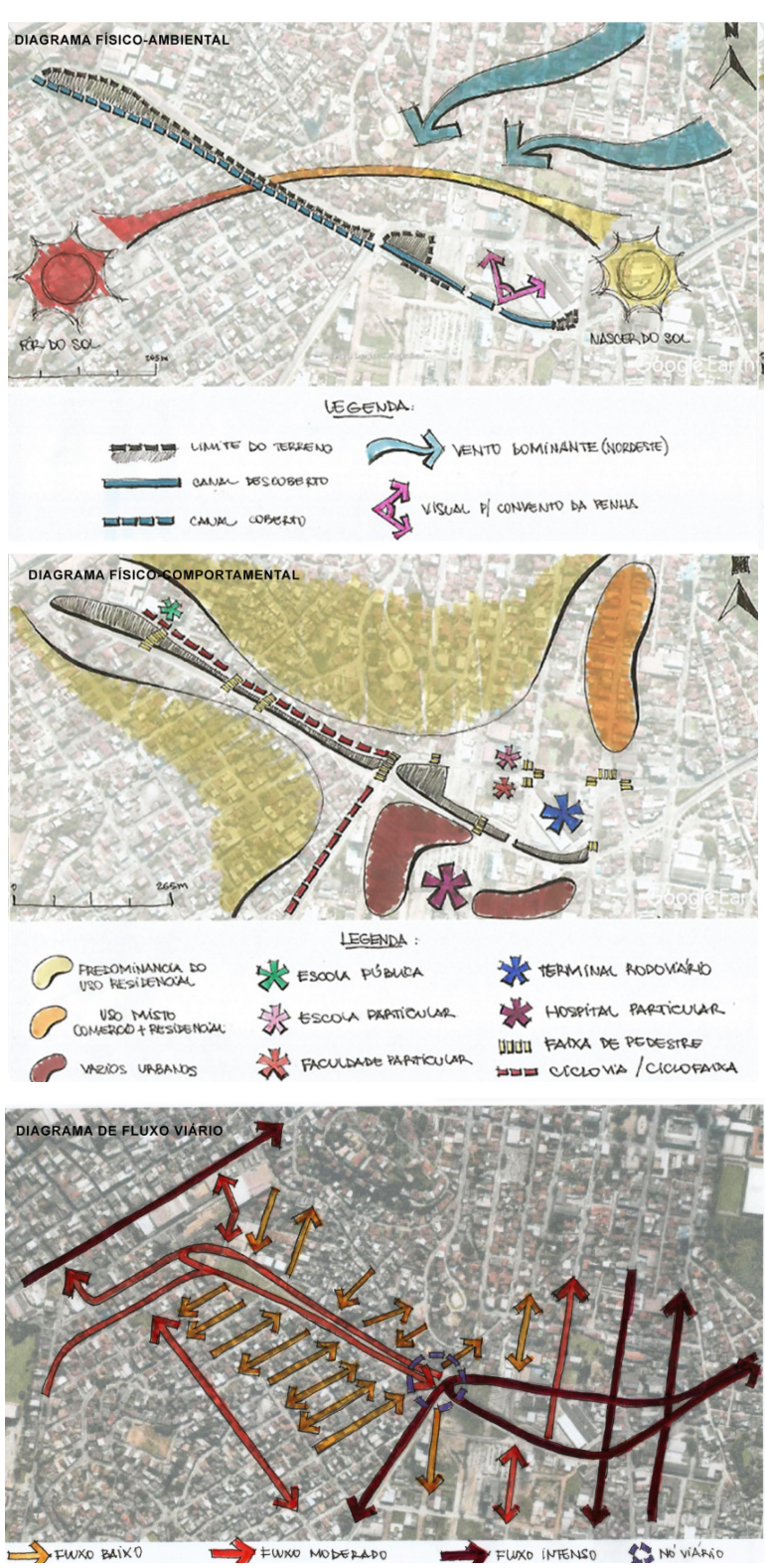

Figura 4. Diagrama Físico-ambiental, diagrama Físico-comportamental e diagrama de Fluxo Viário. Fonte: Elaboração própria - croqui sobre foto aérea disponível no Google Earth, 2017.

usjt • arq.urb • número 24 | janeiro - abril de 2019
O processo metodológico de análise do terreno e seu entorno para realização do ensaio projetual do Parque Linear consistiu no diagnóstico das condicionantes espaciais e ambientais que contextualizam a área, a fim de compreender as potencialidades e vulnerabilidades do local e, assim, definir diretrizes e ações de intervenção. Como resultado dessa etapa foram produzidos três diagramas: físico-ambiental; físico-comportamental e de fluxo viário (ilustrados na Figura 4).

O diagrama "físico-ambiental" apresenta os ventos dominantes, insolação e localização do canal - que possui trechos a céu aberto. O diagrama "físico-comportamental" identifica as infraestruturas de mobilidade existentes (ciclovias, ciclofaixas e faixas de pedestres); o uso e ocupação predominantes nas proximidades do terreno (uso residencial); e as edificações responsáveis por atrair o fluxo de usuários no local. O diagrama de "fluxo viário" evidencia as principais vias de acesso à área, que influenciam diretamente na dinâmica local.
A partir da análise dos diagramas citados foi elaborado um diagrama síntese, apresentado na Figura 5, destacando as potencialidades e vulnerabilidades da área de intervenção.

A partir desse diagrama foi produzida a tabela, indicada como Figura 5, que ilustra as diretrizes e ações de projeto, visando fomentar as potencialidades e mitigar as vulnerabilidades identificadas na fase de análise.

As principais potencialidades identificadas foram a extensa porção territorial oferecida pelo terreno e sua boa conexão com o entorno. Desta forma, torna-se importante, como ação projetual, potencializar a atração de pessoas através de diferentes modais, com incentivo à implantação de ciclovias integradas ao sistema de transporte público, além de diversificar as possibilidades de usos e atividades no local. As vulnerabilidades apontadas estão relacionadas à falta de apropriação da área pelos pedestres. Sendo assim, as diretrizes e ações de projeto devem priorizar a vivência do pedestre, qualificando a infraestrutura de forma a promover a diversidade e segurança à utilização desse espaço. 
Suzany R. Ramos, Larissa Leticia A. Ramos e Ana Paula R. Lyra Espaço público e vitalidade: Parque linear como instrumento de reconciliação em área residual da infraestrutura viária

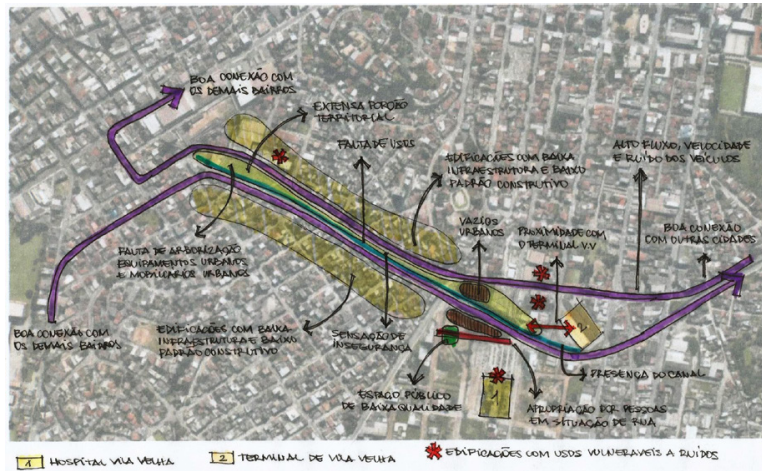

Figura 5. Mapa síntese das potencialidades e vulnerabilidades. Fonte: Elaboração própria - croqui sobre foto aérea dis ponível no Google Earth, 2017.

\begin{tabular}{|c|c|c|}
\hline POTENCIALIDADES & DIRETRIZES & AÇÕES \\
\hline $\begin{array}{l}\text { Boa conexão com os } \\
\text { demais bairros do muni- } \\
\text { cípio e com outras cida- } \\
\text { des; proximidade com o } \\
\text { terminal rodoviário }\end{array}$ & $\begin{array}{l}\text { Potencializar a atra- } \\
\text { ção de pessoas por } \\
\text { diferentes modais } \\
\text { de acesso }\end{array}$ & $\begin{array}{l}\text { Criar estacionamentos de veículos motorizados e não mo- } \\
\text { torizados; conectar a ciclovia do parque às demais ciclovias } \\
\text { da cidade; facilitar o acesso seguro dos pedestres; incenti- } \\
\text { var a utilização do sistema de transporte público. }\end{array}$ \\
\hline Extensa porção territorial & $\begin{array}{l}\text { Utilizar toda área } \\
\text { disponível }\end{array}$ & Setorizar e especificar atividades que permitam a diversidade. \\
\hline $\begin{array}{l}\text { Presença do Canal } \\
\text { Bigossi }\end{array}$ & Valorizar o canal & $\begin{array}{l}\text { Despoluir o canal; criar ambiência confortável às margens do } \\
\text { canal; criar espaços de permanência às margens do canal. }\end{array}$ \\
\hline VULNERABILIDADES & DIRETRIZES & AÇÕES \\
\hline $\begin{array}{l}\text { Alto fluxo e velocidade } \\
\text { dos veículos }\end{array}$ & Priorizar o pedestre & $\begin{array}{l}\text { Traffic Calming: estreitamento de vias; conexões de aéreas } \\
\text { para pedestres; travessias elevadas; ruas compartilhadas. }\end{array}$ \\
\hline $\begin{array}{l}\text { Falta de arborização, } \\
\text { mobiliário urbano, } \\
\text { equipamentos urbanos } \\
\text { e espaços públicos de } \\
\text { qualidade }\end{array}$ & $\begin{array}{l}\text { Qualificar a } \\
\text { infraestrutura }\end{array}$ & $\begin{array}{l}\text { Propor vias e espaços arborizados; propor mobiliário ade- } \\
\text { quado para cada atividade desenvolvida; propor equipa- } \\
\text { mentos urbanos de qualidade para atender a população; } \\
\text { integrar o espaço público presente à área do parque. }\end{array}$ \\
\hline Falta de usos & $\begin{array}{l}\text { Promover a } \\
\text { pluralidade }\end{array}$ & $\begin{array}{l}\text { Diversificar os usos atendendo a demanda de faixas etárias, } \\
\text { gêneros, classes sociais e horários diferentes; incentivar a } \\
\text { cultura local; incentivar o esporte. }\end{array}$ \\
\hline $\begin{array}{l}\text { Apropriação da área por } \\
\text { pessoas em situação } \\
\text { de rua }\end{array}$ & $\begin{array}{l}\text { Utilizar toda área } \\
\text { disponível }\end{array}$ & $\begin{array}{l}\text { Diversificar usos em toda porção territorial do parque a fim } \\
\text { de impedir a apropriação inadequada da área. }\end{array}$ \\
\hline $\begin{array}{l}\text { Sensação de } \\
\text { insegurança }\end{array}$ & $\begin{array}{l}\text { Estimular a sensa- } \\
\text { ção de pertenci- } \\
\text { mento }\end{array}$ & $\begin{array}{l}\text { Propor atividades que envolvam a comunidade e a apropria- } \\
\text { ção do espaço dos moradores locais. }\end{array}$ \\
\hline Vazios urbanos & $\begin{array}{l}\text { Ocupar os vazios } \\
\text { urbanos }\end{array}$ & Integrar os vazios à área do parque, agregando novos usos. \\
\hline Trechos estreitos & $\begin{array}{l}\text { Reorganizar a } \\
\text { malha viária }\end{array}$ & $\begin{array}{l}\text { Reposicionar vias; estreitar vias; integrar área central à } \\
\text { demais áreas identificadas como vazios. }\end{array}$ \\
\hline $\begin{array}{l}\text { Edificações com usos } \\
\text { vulneráveis a ruídos }\end{array}$ & $\begin{array}{l}\text { Proteger as edifica- } \\
\text { ções dos possíveis } \\
\text { ruídos }\end{array}$ & $\begin{array}{l}\text { Intensificar as massas arborizadas e promover usos em horá- } \\
\text { rios e dias restritos em áreas próximas a essas edificações. }\end{array}$ \\
\hline $\begin{array}{l}\text { Edificações do entorno } \\
\text { com baixa infraestrutura } \\
\text { e baixo padrão cons- } \\
\text { trutivo }\end{array}$ & $\begin{array}{l}\text { Incentivar novas } \\
\text { ocupações }\end{array}$ & $\begin{array}{l}\text { Implantar edificações que permitam maior permeabilidade } \\
\text { das quadras próximas ao parque, afim de que se integrem à } \\
\text { intervenção; implantar edificações de uso misto com térreo } \\
\text { livre; determinar um padrão construtivo compatível com a } \\
\text { intervenção. }\end{array}$ \\
\hline
\end{tabular}

Figura 5. Diretrizes e ações de projeto. Fonte: Elaboração própria, 2017. 
Diretrizes e ações para ensaio projetual de Parque Linear

Retomando as discussões apontadas pelos autores anteriormente citados destacam-se as estratégias propostas por Alex (2011) para a implantação de espaços públicos. O autor afirma que é importante propor alternativas para ampliar os espaços de convívio social por meio de desenhos convidativos que privilegiem o acesso, a integração com o entorno e a articulação com o tecido urbano existente. A qualidade desse espaço depende de um desenho interno coerente e de um desenho externo (ruas e tráfego) adequado.

Considerando os conceitos estudados e as análises realizadas na área identificada para proposta de intervenção e a importância dos espaços livres para a cidade, constatou-se que, para se sustentar com naturalidade, os espaços propostos deveriam mesclar usos e usuários. A presença do Canal Bigossi, hoje parcialmente coberto, é um importante elemento ambiental e paisagístico presente na área, e sua valorização no projeto torna-se essencial. Outro ponto importante considerado neste ensaio projetual foram as remodelações da malha viária, visando uma apropriação segura do espaço público proposto.

O esquema representado na Figura 6 a seguir ilustra a proposta de intervenção realizada na maIha viária da área de estudo, sendo esta definidora da estrutura formal de implantação do ensaio projetual do parque linear. Na proposta foram utilizadas estratégias de traffic calming como: ruas compartilhadas; estreitamento de vias; travessias

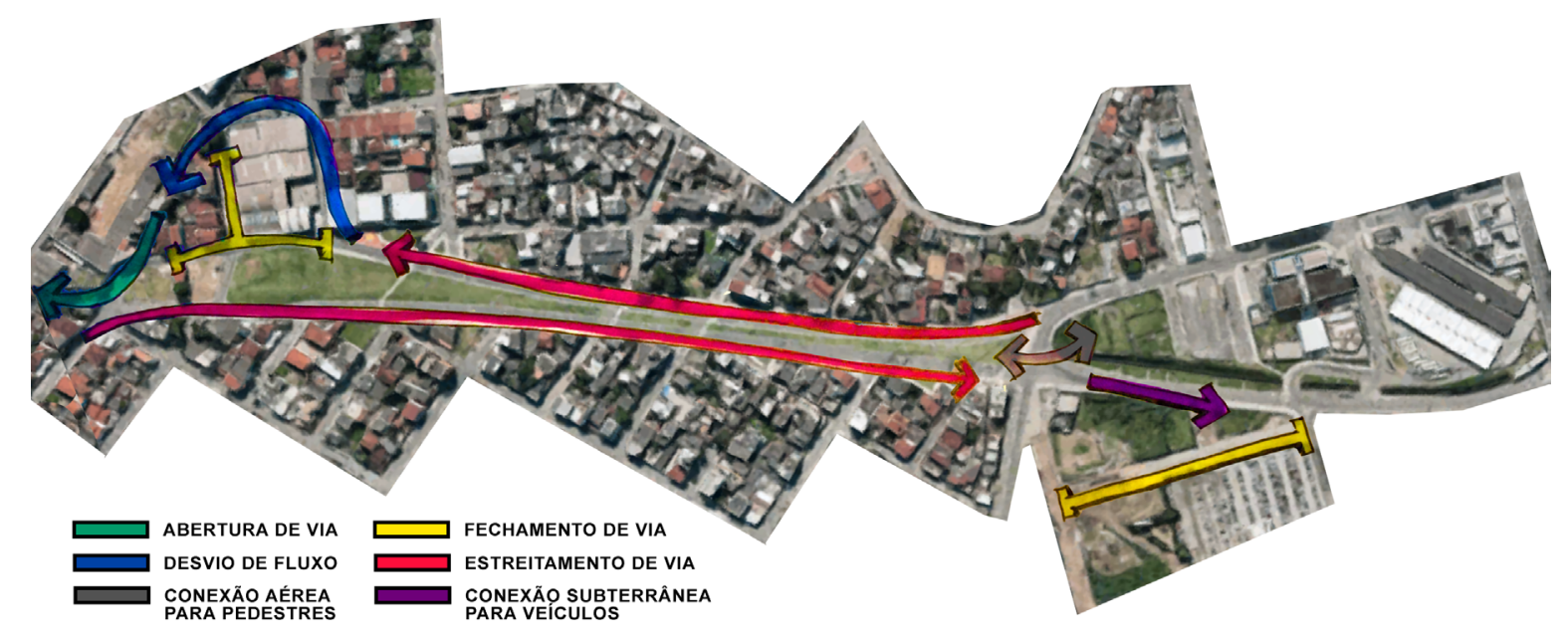

Figura 6. Esquema de Intervenção Viária. Fonte: Elaboração própria - croqui sobre foto aérea disponível no Google Earth, 2017. 
elevadas para pedestres e arborização de vias, a fim de priorizar a circulação livre e segura dos pedestres e ciclistas.

Destaca-se no esquema apresentado na Figura 6 a necessidade do estreitamento das vias para dar lugar a mais espaço para a implantação do parque linear, uma vez que estas restringiam as dimensões da área em sua largura e limitava as apropriações. O usuário, de acordo com a realidade local atual, precisa atravessar 3 (três) faixas de rolamento - com fluxo de veículos em alta velocidade - para chegar ao canteiro central. A proposta de intervenção diminui as vias para uma faixa de rolamento em cada sentido, sendo previstos recuos para baia de transporte coletivo ao longo do percurso do terreno.

Outro ponto importante é a necessidade de conexões alternativas que atendam ao mesmo tempo a demanda de pedestres e veículos no local. Como ilustra a Figura 6, apresentada anteriormente, foi proposta a criação de uma conexão aérea para pedestres - onde foi identificado na etapa de diagnóstico (Figura 4, mapa de fluxo viário) um nó viário decorrente do alto fluxo de veículos - e uma conexão subterrânea para veículos, a fim de tornar o percurso do pedestre entre as áreas propostas para o parque linear mais seguro.

O ensaio projetual considerou a pluralidade e a reconciliação como conceitos norteadores da proposta de intervenção, visando a restituição do contato entre a população e o meio ambiente. A "pluralidade" é traduzida na proposta pela diversidade de usos, públicos, atividades e diferentes possibilidades de acessos. A "reconciliação" significa o restabelecimento da boa relação entre homem e o meio ambiente, essa é revelada no projeto com a reinserção do Canal Bigossi no perfil paisagístico da área de intervenção, a fim de resgatar memórias e valorizar esse bem natural presente no local.

O ensaio tem como premissa transformar a área num equipamento público de escala municipal, cujo objetivo é proporcionar à população o acesso ao lazer, entretenimento, cultura, saúde e diversas outras atividades, num local que abriga a pluralidade de idades, gêneros, raças e classes sociais, a fim de manter a vivacidade durante todos os períodos do dia. Essas atividades proporcionam maior envolvimento dos usuários estimulando o pertencimento - sentimento considerado fundamental para a manutenção e evolução do espaço coletivo.

A proposta projetual do Parque Linear foi realizada considerando a linearidade do eixo do Canal Bigossi e sua conexão paisagística, e a intervenção compreende uma área de aproximadamente $37.000 \mathrm{~m} 2$. O agrupamento de usos e atividades em determinados setores - detalhados na sequência - permitiu nomeá-los em Setor 1 - "Entretenimento"; Setor 2 - "Contemplação"; 
Setor 3 - "Cultura" e Setor 4 - "Serviço", conforme ilustrado na Figura 7 a seguir. Ressalta-se que no ensaio projetual a divisão do parque em setores teve como objetivo principal facilitar a visualização do projeto devido sua grande extensão. Além disso, a diversidade de usos entre os setores busca atingir um público variado e a interação entre os diferentes grupos sociais que podem usufruir desses espaços.

O Setor 1, intitulado "Entretenimento", apresentado na Figura 8 a seguir, está situado em uma das extremidades do parque, e, pela proximidade com uma Escola Municipal de Ensino Fundamental, foram propostas atividades esportivas e de vivência. Por toda área, e ao longo do Canal Bigossi, foram previstos espaços de permanên- cia e convívio para todos os públicos (crianças, jovens, adultos e idosos).

As principais potencialidades identificadas foram a extensa porção territorial oferecida pelo terreno e sua boa conexão com o entorno. Desta forma, torna-se importante, como ação projetual, potencializar a atração de pessoas através de diferentes modais, com incentivo à implantação de ciclovias integradas ao sistema de transporte público, além de diversificar as possibilidades de usos e atividades no local. As vulnerabilidades apontadas estão relacionadas à falta de apropriação da área pelos pedestres. Sendo assim, as diretrizes e ações de projeto devem priorizar a vivência do pedestre, qualificando a infraestrutura de forma a promover a diversidade e segurança à utilização desse espaço.

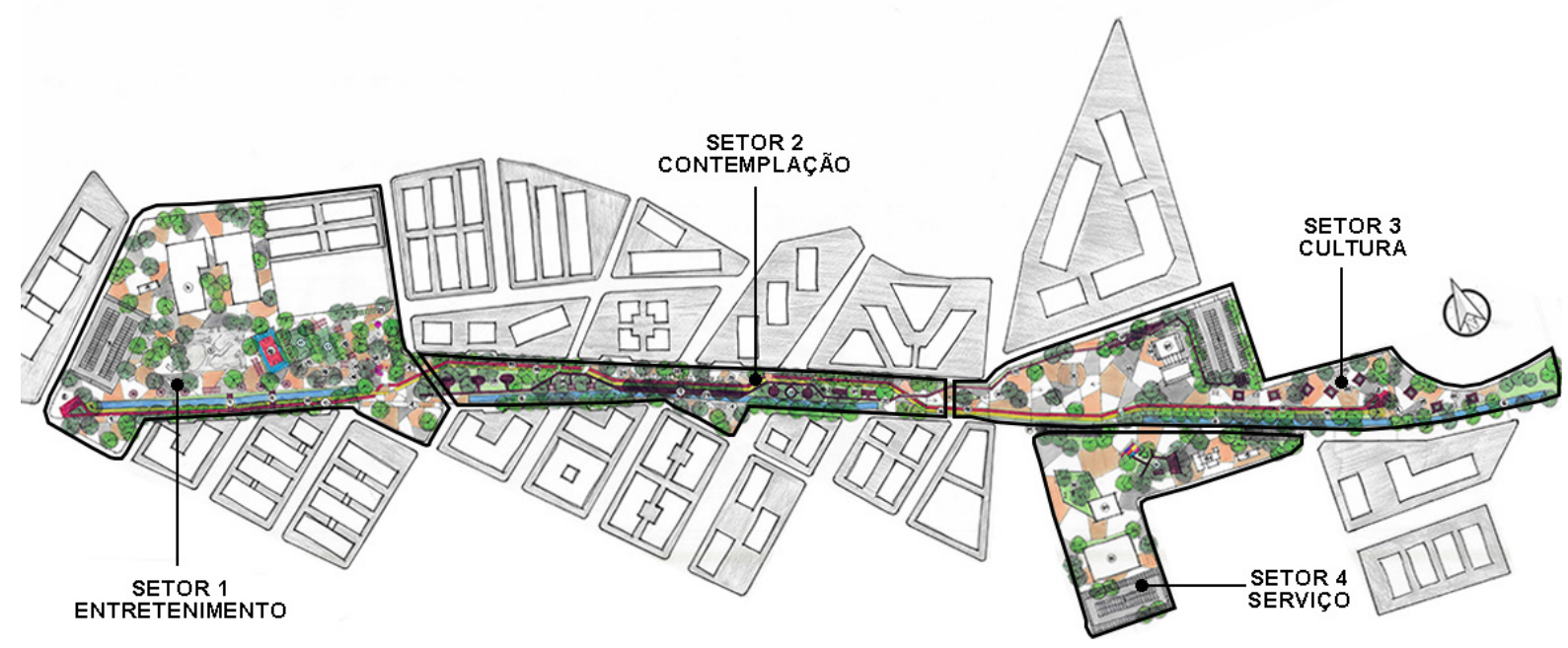

Figura 7. Croqui de Implantação do Parque Linear. Fonte: Elaboração própria a partir de arquivo CAD em planta baixa do município de Vila Velha disponibilizado pela Prefeitura Municipal, 2017. 
O Setor 1, intitulado "Entretenimento", apresen-

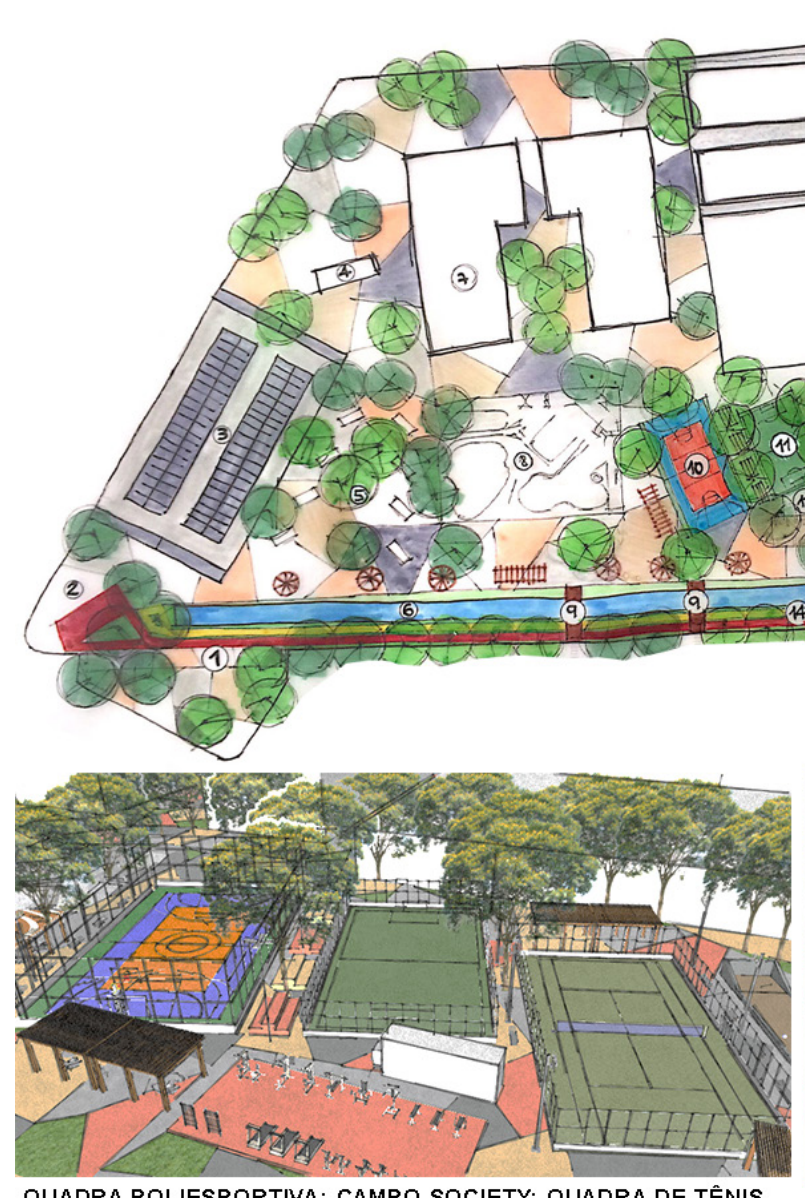

QUADRA POLIESPORTIVA; CAMPO
VESTIARIOE ECADEMIA POPULAR. POSTO COMUNITARIO DE SEGURANCA 1. HORTA COMUNITÁRIA
Figura 8. Detalhe de implantação do Setor do setor. Fonte: Elaboração própria, 2017. tado na Figura 8 a seguir, está situado em uma das extremidades do parque, e, pela proximidade com uma Escola Municipal de Ensino Fundamental, foram propostas atividades esportivas e de vivência. Por toda área, e ao longo do Canal Bigossi, foram previstos espaços de permanên1. RUA COMPARTILHADA
2. TERMINAL DE BIKE COMPARTILHADA ESTACIONAMENTO PUUBLICO 6. CANAL BIGOSSI
7. EDIFICIO HIBRIDO
8ISTA DE SKATE PASSARELA SOBRE CANAL 10. QUADRA POOLESPORTIVA 1. CAMPO SOCIETY 13. ACADEMIA POPULAR 4. PISTADE COOPER 16. ACADEMIA TERCEIRA IDADE 17. QUADRADE TENIS 18. CAMPO DE BOCHA MESAS DE JOGOS cia e convívio para todos os públicos (crianças, jovens, adultos e idosos).

Para o Setor 2, nomeado "Contemplação", apresentado na Figura 9, foram reservados espaços para maior contato com a natureza. Esse contato foi proposto através de percursos arborizados que conduzissem às áreas voltadas para atividades de relaxamento e contemplação. Para promover maior movimentação e presença de pessoas, a proposta visa à instalação de quiosques de informação e serviços, além de uma área para feiras-livre em dias específicos da semana.

O Setor 3 e 4, ilustrados na Figura 10, estão localizados extremidade leste do Parque Linear. Para o setor 3, intitulado "Cultura" a proposta incentivar à cultura através da implantação de um Centro Cultural onde poderiam ser oferecidos cursos visando a inclusão social da comunidade local. A implantação desse edifício foi proposta em pilotis afim de liberar o térreo para apresentações, resultando em uma área de vivência coberta que poderia ser utilizada para eventos sazonais.

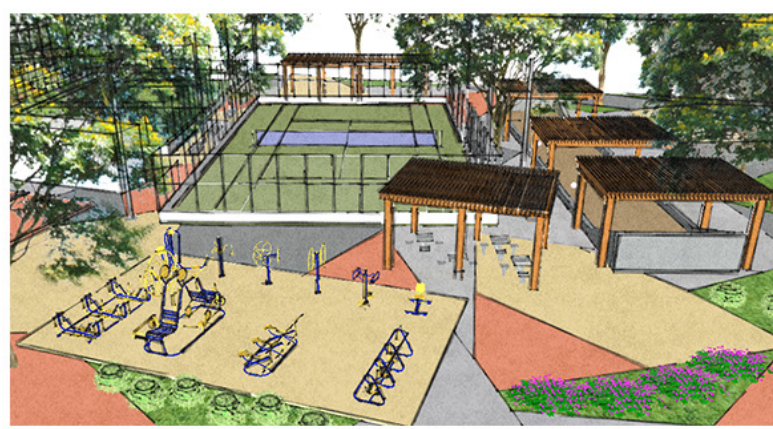

ACADEMIA TERCEIRA IDADE; CAMPO DE BOCHA
MESAS DE JOGOS

O Setor 4, intitulado "Serviço", possui restrições quanto a sua localização devido a presença de um hospital particular em sua proximidade. Dessa maneira propôs-se a instalação de serviços de saúde pública, acompanhando o uso do entorno, além de outros serviços como segurança pública e informação. Para mesclar o uso desse setor foi prevista uma área de permanência e lazer para a população, como ilustrado na Figura 10. 


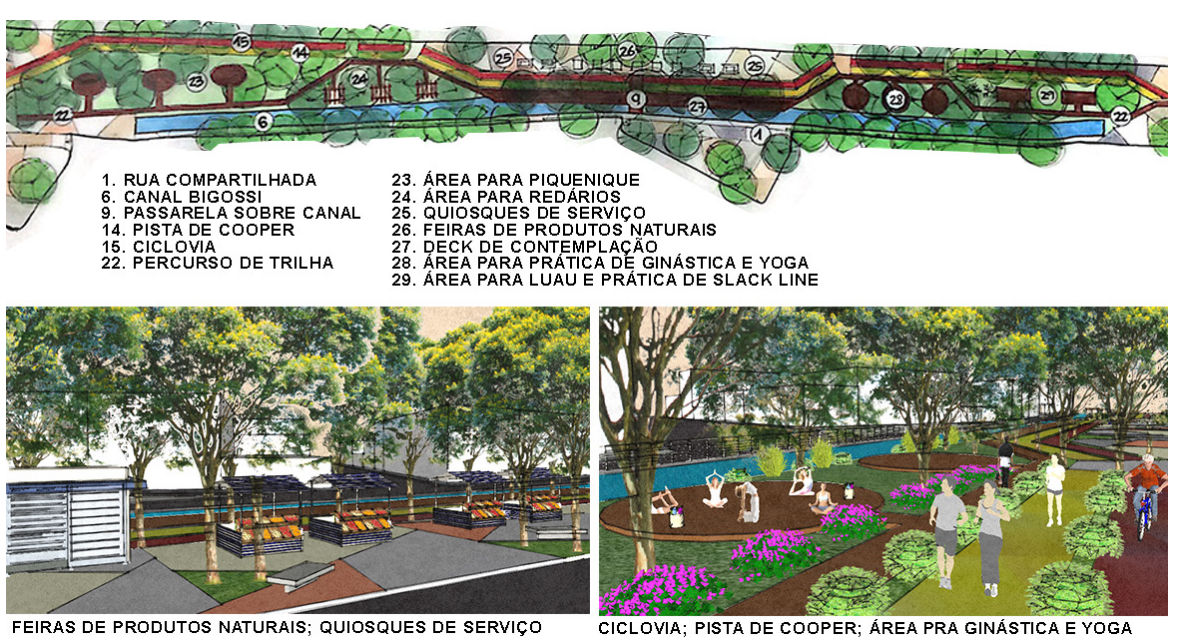

Figura 9. Detalhe de implantação do Setor 2 - "Contemplação" e imagens ilustrativas das propostas de equipamentos e usos do setor. Fonte: Elaboração própria, 2017.
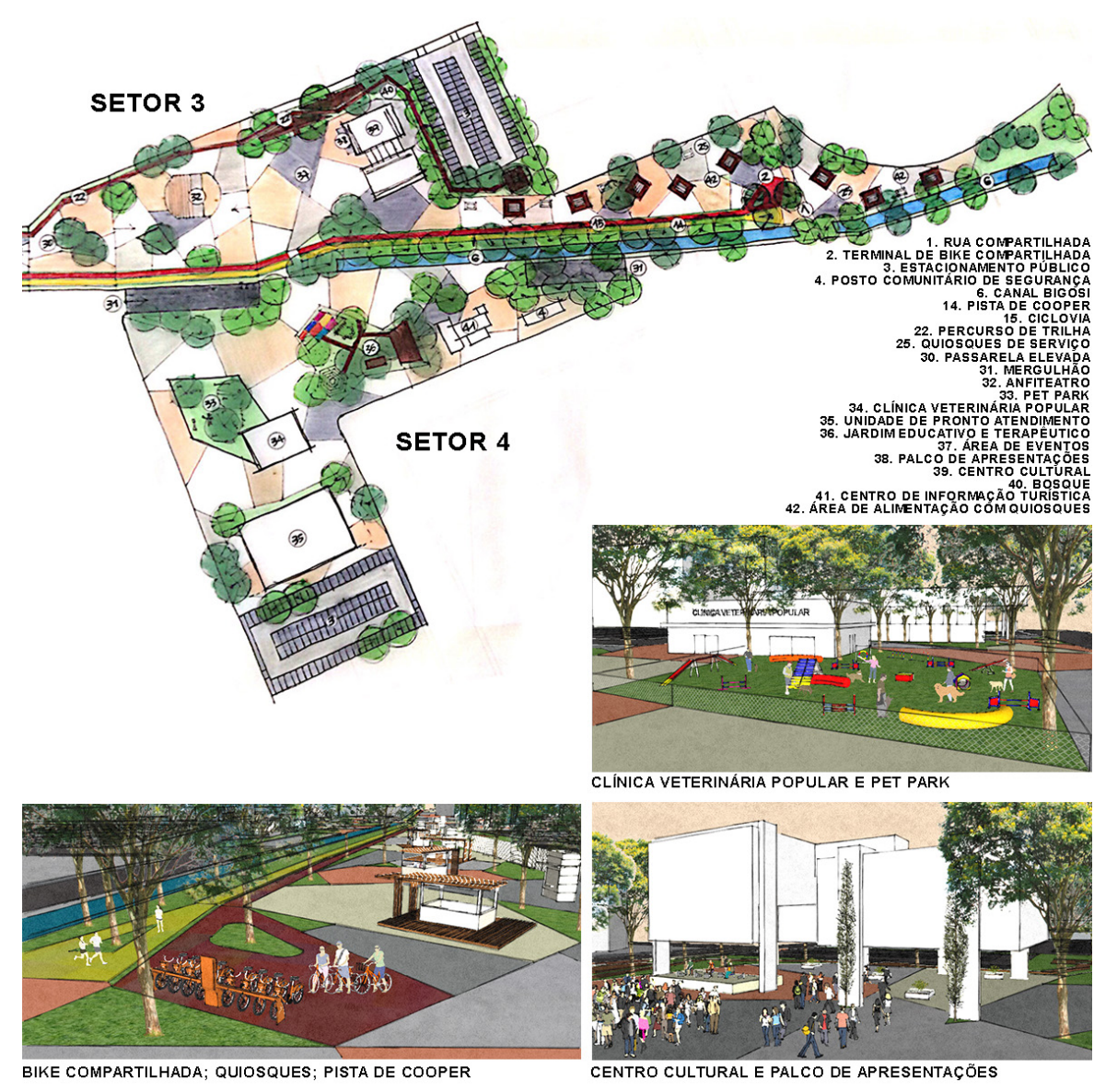

Figura 10. Detalhe de implantação do Setor 3 - "Cultura" e Setor 4 - "Serviços". Imagens ilustrativas das propostas de equipamentos e usos. Fonte: Elaboração própria, 2017. 
O sistema integrado de ciclovias previsto para toda extensão do parque foi sugerido a fim de conectar o parque às demais ciclovias da cidade, além de incentivar o uso das bicicletas através de terminais compartilhados já instalados pela prefeitura local. A proximidade do parque com o Terminal Rodoviário Municipal de Vila Velha já é um bônus de mobilidade e a disposição de pontos de ônibus por toda extensão do parque seria um incentivo a utilização do transporte coletivo, evitando o acesso ao local através de veículos motorizados individuais.

\section{Considerações finais}

A cidade é responsável por produzir espaços de qualidade que permitam a interação entre pessoas de diversos grupos sociais. Estudos comprovam o impacto dos espaços livres de uso público na qualidade de vida da população urbana, devido a influência nas relações entre as pessoas e o meio em que habitam. O planejamento urbano tem fundamental importância nessa questão, uma vez que é responsável por pensar a cidade de forma inclusiva, considerando o dinamismo que a criação desses espaços livres oferece a partir da diversidade de apropriações possíveis.

A partir disso, o ensaio projetual do parque linear para a Região Central de Vila Velha - ES buscou ressaltar a vivência do pedestre em um local que sofreu um processo de desapropriação e urbanização pensada apenas para a o veículo. A área remanescente da malha viária resultante deste processo gerou espaços ociosos e inseguros para a população local, uma vez que aumentou o fluxo e a velocidade dos veículos nas vias.

Atualmente existem intervenções para a recuperação de rios urbanos por todo o mundo, e nesse sentido o projeto do parque linear visou resgatar este elemento natural importante para região, procurando reconciliar não só a relação entre a população e o bem natural. A pluralidade dos usos e atividades propostas visam criar, acima de tudo, a sensação de pertencimento e estimular o envolvimento da população com o espaço público do parque, permitindo maior interação e relacionamento entre pessoas com experiências e vivências diferentes, e contribuindo para o senso de comunidade.

Esse projeto, apesar de ser um ensaio projetual, desenvolvido em âmbito acadêmico e a nível preliminar, buscou, sobretudo, reforçar a importância dos espaços públicos como instrumento de reconciliação e de vitalidade urbana das cidades; estimular pensamentos críticos sobre as intervenções realizadas pelas prefeituras, que atualmente reproduzem modelos genéricos de espaços recreativos e esportivos sem entender a real necessidade da comunidade local, e por fim, alertar sobre os projetos de canalização e fechamento dos rios urbanos, que são tão importantes para qualidade de vida da população, dando lugar a novas vias para facilitar o deslocamento de veículos pela cidade, e ignorando a importância da cidade caminhável. 


\section{Referências:}

AGUIAR, Douglas; NETTO, Vinicius M. (Org.). Urbanidades. Rio de Janeiro, RJ: Folio Digital: FAPERJ, 2012.

ALEX, Sun. Projeto da praça: convívio e exclusão no espaço público. 2. ed. São Paulo: Senac São Paulo, 2011.

BAVA, Silvio Caccia. Dilemas da gestão municipal democrática. Instituto Polis, 2000. Disponível em: <http://www.polis.org.br/uploads/820/820.pdf> Acesso em: 03 mar. 2019

BRANDÃO, Pedro. A identificação dos lugares e a sua representação coletiva: bases de orientação para concepção, qualificação e gestão do espaço público. Série Política de Cidades -3 . Centro de Sistemas Urbanos e Regionais (CESUR), Departamento de Engenharia Civil do Instituto Superior Técnico, Universidade Técnica de Lisboa, 2008.

BRASIL. Lei no 10.257, de 10 de julho de 2001. Estatuto da Cidade e Legislação Correlata. 2. ed., atual. Brasília: Senado Federal, Subsecretaria de Edições Técnicas, 2002. 80 p.

DEL RIO, Vicente. Introdução ao desenho urbano no processo de planejamento. São Paulo: Pini, 1990.

GATTI, Simone. Coordenação do Programa Soluções para Cidades. Espaços públicos: diagnós- tico e metodologia de projeto. São Paulo, $A B C P$, 2013. Disponível em: <http://www.solucoesparacidades.com.br/wp-content/uploads/2013/11/Manual\%20de\%20espacos\%20publicos.pdf.> Acesso em: 17 de abril de 2017.

GEHL, Jan. Cidades para pessoas. São Paulo, SP: Perspectiva, 2015.

MACEDO, Silvio; SAKATA, Francine Gramacho. Parques Urbanos no Brasil = Brazilin Urban Parks. 2. ed. São Paulo. Editora da Universidade de São Paulo: Imprensa Oficial do Estado de São Paulo, 2003 - [Coleção Quapá]

MARTINS, Juliana E. Prado; OLIVEIRA, Marcelo de; THOMAZ, Vitor Cunha. Implantação do Corredor Bigossi: um caso de sucesso em desapropriações urbanas. In II Congresso Consad de Gestão Pública - Painel 53: Estratégias inovadoras de contratação, organização e serviços. Brasilia/DF, 2009.

MASCARÓ, J. L. Infra-estrutura da Paisagem. Porto Alegre: Masquatro Editora, 2008.

MONGIN, Olivier. A condição urbana: a cidade na era da globalização. Tradução Leticia Martins de Andrade. São Paulo: Estação Liberdade, 2009.

NETTO, Vinicius M. Cidade e sociedade: as tramas da prática e seus espaços. Porto Alegre: Sulina 2014. 
NETTO, Vinicius M; SABOYA, Renato T. de; VARGAS, Júlio Celso; CARVALHO, Thereza (org.). Efeitos da arquitetura: os impactos da urbanização contemporânea no Brasil. Brasília: FRBH, 2017.

NYGAARD, Paul Dieter. Espaço da cidade: segurança e participação popular. Porto Alegre: Livraria do Arquiteto, 2010.

RAMOS, L. A.; JESUS, L. N. Sistema de espaços livres de uso público: um estudo sobre o Grande Centro de Vila Velha. V!RUS, São Carlos, n. 14, 2017. Disponível em: <http://www.nomads.usp.br/ virus/virus $14 /$ ?sec $=4 \&$ item $=10$ \&lang=pt $>$. Acesso em: 22 jul. 2018.

ROGERS, Richard. Cidades para um pequeno planeta. Versão portuguesa de Anita Regina Di Marco. Barcelona: Editorial Gustavo Gili, 2001.

SABOYA, Renato. A importância da participação popular. Blog urbanidades, 2014. Disponível em: <https://urbanidades.arq.br/2014/01/a-importancia-da-participacao-popular> Acesso em: 03 mar. 2019

SAKATA, Francine Gramacho. Parques Urbanos no Brasil - 2000 a 2017. 2018.348 p. Tese (Doutorado - Arquitetura e Urbanismo) - Faculdade de Arquitetura e Urbanismo, Universidade de São Paulo, São Paulo, 2018.

SANTIAGO, Paola Caiuby; MARCHESANO, Tiago. Guia do Espaço Público. 2. ed. São Paulo: Conexão Cultural, 2016.
SCALISE, Walnyce. Parques Urbanos - evolução, projeto, funções e uso. Revista Assentamentos Humano, Marília, v4, n. 1, p17-24, 2002.

SEMPLA. Secretaria Municipal de Planejamento Orçamento e Gestão. Perfil socioeconômico por bairros. Vila Velha em Dados. Vila Velha, outubro 2013.

SERPA, Angelo. O espaço público na cidade contemporânea. 2. ed. São Paulo, SP: Contexto, 2013.

SOLUÇÕES PARA CIDADES. Projeto Técnico: parques Lineares como medidas de manejo de águas pluviais. São Paulo, ABCP. (Sem data). Disponível em: <http://www.solucoesparacidades. com.br/wp-content/uploads/2013/10/AF_Parques\%20Lineares_Web.pdf.> Acesso em: 17 abril de 2017.

VILA VELHA. Lei $n^{\circ} 4.707$ de 10 de setembro de 2008. Institucionalização dos bairros nas Regiões Administrativas, os limites e a denominação dos mesmos e os critérios para organização e criação de bairros, no perímetro urbano do Município. Prefeitura Municipal de Vila Velha - ES, 2008.

VILA VELHA. Projeto de Lei Complementar $n^{\circ}$ 065/2018. Revisão decenal da Lei Municipal $\mathbf{n}^{\circ}$ 4.575/2007 - Plano Diretor Municipal do município de Vila Velha. Prefeitura Municipal de Vila Velha - ES, 2018. 